\title{
Aktivitas Immunodulator Ekstrak Etanol Umbi Bawang Merah (Allium cepa L.) terhadap Respon Imun Non Spesifik pada Mencit Jantan Galur Balb/C dengan Metode Carbon Clearance
}

\author{
Diska Anggraeni Alfitasari ${ }^{1}$, Anjar mahardian Kusuma ${ }^{1}$, Zainur Rahman Hakim ${ }^{1}$ \\ ${ }^{1}$ Fakultas Farmasi Universitas Muhammadiyah Purwokerto \\ Email: Diskaalfitasari07@gmail.com
}

\begin{abstract}
The content of flavonoids on onion useful to maintain endurance. This research aims to know the activity of exstract immunodulator of onion bulb ethanol (Allium cepa $L$ ) on phagocytic activity in male mice balb/c with varian dose and campored immunodulator activity with positive control. This study is an experimental reseach with Completely Randomized Design (CRD). Preparation of extract ethanol onion roots done by maceration using $96 \%$ ethanol for 9 hours. The test performed on samples which consist of 25 mice with carbon clearance method, devided into 5 groups, which are : $\mathrm{K}$ - (without treatment), $\mathrm{k}+$ (with imboos 13,3 ml/Kg Bw), P1 (dose 12\%), P2 (dose 24\%), and P3 (dose $48 \%$ ). The test performed for 5 days, and on the $7^{\text {th }}$ day injected carbon (pelicans) as much $0,1 \mathrm{ml} / 10 \mathrm{gr}$ Weight intravenousty, their blood taken before carbon injection (minute 0) and minute 4, 8, 12, and 16. After their transmittance measure using spectrophotometer at $600,5 \mathrm{~nm}$ wavelength. This research shows that extract ethanol of onion balb has immunodulator activity effect on non-specific immune response on male mice balb/c with carbon clearance method. The dose of $12 \%(\mathrm{v} / \mathrm{v}), 24 \%(\mathrm{v} / \mathrm{v})$ and $48 \%(\mathrm{v} / \mathrm{v})$ dose have lower immunostimulatory capacity than positive control.
\end{abstract}

Keywords : Flavonoid, Ethanol extracts onion bulb, carbon clearance, immunodulatory.

\begin{abstract}
Abstrak
Kandungan flavonoid pada umbi bawang merah berguna untuk menjaga daya tahan tubuh. Penelitian ini bertujuan untuk mengetahui adanya aktivitas immunodulator ekstrak etanol umbi bawang merah (Allium cepa $L$ ) terhadap aktivitas fagositosis pada mencit jantan galur balb/c dengan variasi dosis dan dibandingkan aktivitas immunodulator dengan kontrol positif. Penelitian eksperimental ini menggunakan rancangan acak lengkap (RAL). Pembuatan ekstrak etanol umbi bawang merah dilakukan dengan maserasi menggunakan etanol $96 \%$ selama 9 jam. Pengujian dilakukan pada sampel yang terdiri dari 25 ekor mencit dengan metode carbon clearance, dibagi menjadi 5 kelompok yaitu K- (tanpa perlakuan), $\mathrm{K}+$ (imboos 13,5 ml/kg BB), p1 (dosis 12\%), p2 (dosis 24\%), dan p3 (dosis $48 \%$ ). Perlakuan dilakukan selama 5 hari, dan pada hari ke-7 diinjeksi karbon (tinta pelikan) sebanyak $0,1 \mathrm{ml} / 10 \mathrm{gram}$ BB secara intravena. Darah mencit diambil sebelum penyuntikan karbon (menit ke-0) dan menit ke 4, 8, 12 dan 16. Diukur transmitannya dengan menggunakan spektrofotometer pada panjang gelombang $600,5 \mathrm{~nm}$. Ekstrak etanol umbi bawang merah (Allium cepa $L$ ) mempunyai efek aktivitas immunodulator terhadap respon imun non spesifik pada mencit jantan galur balb/c dengan metode carbon clearance. Dosis $12 \%(\mathrm{v} / \mathrm{v})$, dosis $24 \%$ (v/v) dan, dosis $48 \%$ (v/v) mempunyai kemampuan immunostimulan lebih rendah dari kontrol positif.
\end{abstract}

Kata Kunci : Flavonoid, Ekstrak etanol umbi bawang merah, carbon clearance, immunodulator.

\section{Pendahuluan}

Lingkungan di sekitar manusia mengandung berbagai jenis patogen, misalnya bakteri, virus, fungus, protozoa dan parasit yang dapat menyebabkan infeksi pada manusia. Untuk menghadapi senyawa patogen tubuh manusia dibekali sistem pertahanan dirinya yang disebut dengan sistem imun (Corwin, 2009). Imunomodulator merupakan zat atau obat yang dapat mengembalikan keseimbangan sistem kekebalan tubuh yang terganggu dengan cara merangsang dan memperbaiki fungsi sistem kekebalan.

Beberapa efek samping yang timbul setelah penggunaan obat kimia sintetis menjadi salah satu alasan mengapa masyarakat kembali menggunakan produk bahan alam dalam menjaga kesehatan maupun pengobatan. Salah satu produk alam berupa tanaman yang dapat digunakan secara tradisional untuk kesehatan adalah bawang merah (Allium cepa L.) (Rahayu, 1999). Bawang merah digunakan untuk mengobati berbagai macam penyakit, misalnya: batuk, pilek, perut kembung, antiinflamasi, meningkatkan daya tahan tubuh, sariawan, mengobati sakit kepala dan menurunkan demam.

Imunomodulator adalah substansi atau obat yang dapat memodulasi fungsi dan aktivitas sistem imun Imunomodulator Kebanyakan tanaman obat yang telah diteliti membuktikan bahwa adanya kerja imunostimulator, Imunostimulator ditunjukan untuk perbaikan fungsi imun pada kondisi-kondisi imunosupresi. Kelompok obat ini dapat memperngaruhi respon imun seluler maupun humoral. Bahan yang dapat menstimulasi sistem imun disebut biological response modifiers (BRM), dibagi menjadi dua kelompok yaitu bahan biologis dan sintetik. Pemakaian tanaman obat sebagai 
imunostimulator dengan maksud menekan atau mengurangi infeksi virus dan bakteri intraseluler, untuk mengatasi imunodefisiensi atau sebagai perangsang pertumbuhan sel-sel pertahanan tubuh dalam sistem imunitas (Block el al., 2003).

Pendapat lain menyatakan Imunomodulator adalah zat yang dapat mengatur system imun, baik berupa mengembalikan dan memperbaiki sistem imun yang fungsinya terganggu atau untuk menekan yang fungsinya berlebihan (Baratawidjaja, 2006).

Penelitian Jaelani (2007) yang mengungkapkan bahwa kandungan flavonoid pada umbi bawang merah berguna untuk menjaga daya tahan tubuh dengan memakan sekurang-kurangnya satu siung bawang merah segar sebagai kudapan, lalapan, atau teman makan setiap hari. Bawang merah mempunyai efek yang sedang terhadap immunodulator dilihat dari kandungan flavonoid yang terkandung pada bawang merah yang dapat digunakan sebagai acuan bahwa bawang merah dapat meningkatkan sistem pertahanan imun.

Berdasarkan hal tersebut di atas, maka perlu dilakukan penelitian lebih lanjut tentang aktivitas immunodulator dari ekstrak etanol umbi bawang merah (Allium cepa $L$ ) terhadap respon sistem imun non-spesifik pada mencit jantan galur BALB/C dengan melihat aktivitas fagositosisnya.

\section{Metode Penelitian}

Alat yang digunakan meliputi kandang mencit, labu takar, gelas beker, gelas ukur, tabung reaksi, spektrofotometer, kuvet, spuit injeksi, jarum berujung tumpul, pipet ukur, pipet tetes, pipet mikro, toples.

Bahan yang diperlukan meliputi umbi bawang merah, mencit jantan galur balb/c berumur 8-12 minggu, dengan berat 20-22 gram, etanol, $\mathrm{NaCl}$ p.a, asam asetat $1 \%$, natrium sitrat, tinta pelican $\mathrm{B} 17, \mathrm{H}_{2} \mathrm{SO}_{4}$, dan methanol.

\section{Prosedur Penelitian}

1. Determinasi Tanaman dilakukan di Laboratorium Ekologi dan Biosistematik Fakultas Biologi Universitas Jendral Soedirman.

2. Pembuatan Ekstrak Etanol Umbi Bawang Merah (Allium cepa L.). Ekstraksi dilakukan dengan cara maserasi menggunakan etanol 96\% yang dilakukan selama 9 jam dengan perbandingan etanol : simplisia yaitu $1: 4$, dan dilakukan remaserasi, lalu filtrate dikumpulkan dan diuapkan dengan menggunakan evaporator hingga diperoleh Ekstrak Etanol Umbi Bawang Merah (Allium cepa L.) kental

3. Identifikasi Flavonoid

a. Sebanyak $1 \mathrm{ml}$ sampel ditambahkan metanol sampai terendam lalu dipanaskan kemudian filtratnya ditambahkan $\mathrm{H}_{2} \mathrm{SO}_{4}$, terjadi pe rubahan warna dari kuning kehijauan menjadi warna merah karena penambahan $\mathrm{H}_{2} \mathrm{SO}_{4}$ menunjukkan adanya senyawa flavonoid.

b. Sebanyak $1 \mathrm{ml}$ sampel ditambahkan dengan 1 tetes $\mathrm{NaOH} 4 \%$. Adanya senyawa flavonoid ditunjukan dengan timbulnya warna kuning yang konstan.

4. Pembuatan Suspensi Karbon dibuat dengan cara mensuspensikan $1,6 \mathrm{ml}$ tinta pelikan dalam $8,4 \mathrm{ml}$ gelatin $15 \mathrm{~b} / \mathrm{v}$ dalam larutan fisiologis $\mathrm{NaCl}$.

5. Penetapan Kadar Karbon.Tinta pelikan sebanyak 5 gram dimasukkan ke dalam cawan penguap dan diuapkan dalam oven pada suhu $105^{\circ} \mathrm{C}$ selama 30 menit. Pengeringan kemudian dilanjutkan dalam desikator sampai didapatkan berat yang konstan

6. Pembuatan Kurva Baku Karbon. Tinta cina sebanyak 5,42 $\mathrm{mL}$ didispersikan dalam 100 $\mathrm{mL}$ asam asetat $1 \%$ sehingga konsentrasinya menjadi $1 \mathrm{~mL} / \mathrm{mL}$. masing-masing larutan dipipet sebanyak $1 ; 1,5 ; 2 ; 2,5$,dan $3 \mathrm{~mL}$, kemudian dicukupkan dengan asam asetat $1 \%$ hingga volumenya $50 \mathrm{~mL}$, sehingga didapatkan kadar karbon 20; 30; 40; 50 dan 60 $\mu \mathrm{l} / \mathrm{mL}$. masing-masing kadar tersebut dipipet sebanyak $4 \mathrm{~mL}$ dan selanjutnya ditambahkan darah mencit setelah dihomogenkan dan di sentrivuge ukur absorbansinya pada panjang gelombang $600,5 \mathrm{~nm}$.

7. Perlakuan Hewan Uji

a. Satu kelompok (kontrol negatif) mencit jantan galur Balb/c diberikan aquadest 0,5 $\mathrm{ml} / 20$ gr BB selama 5 hari satu kali sehari secara per oral.

b. Tiga kelompok (kelompok perlakuan) mencit jantan galur Balb/c diberikan perasan umbi bawang merah (Allium cepa L.) selama 5 hari satu kali sehari secara per oral dengan dosis $12 \%$; $24 \%$; dan $48 \%$ yang dilarutkan dalam $\mathrm{NaCMC} 0,5 \%$.

c. Satu kelompok (kontrol positif) mencit mencit jantan galur Balb/c diberikan imboos cair $13,5 \mathrm{mg} / \mathrm{kg}$ BB selama 5 hari satu kali sehari secara per oral.

d. Hari ke-7 (48 jam setelah perlakuan terakhir), mencit dari semua kelompok diambil darahnya melalui vena ekor (menit ke-0) diteteskan dalam plat tetes yang berisi EDTA 0,1\% (antikoagulan) lalu dipipet sebanyak $50 \mu \mathrm{l}$ kemudian dilisis dengan $4 \mathrm{ml}$ asam asetat $1 \%$.

e. Mencit dari semua kelompok diinjeksi dengan karbon (tinta pelikan) $0,1 \mathrm{ml} / 10$ gram BB mencit melalui vena ekor.

f. Darah diambil setiap 4 menit sekali ( pada menit ke 4; 8; 12 dan 16 ) diteteskan dalam plat tetes yang berisi natrium sitrat (antikoagulan) lalu dipipet sebanyak $50 \mu \mathrm{l}$ 
kemudian dilisis dengan $4 \mathrm{ml}$ asam asetat $1 \%$.

g. Diukur transmitannya dengan menggunakan spektrofotometer pada panjang gelombang 600,5 nm.

h. Aktifitas fagositik ditentukan berdasarkan perbandingan antara kemiringan garis regresi linier antara waktu ( $\mathrm{x}_{0}$ terhadap 100$\%$ transmitan (y) pada kelompok perlakuan dan kontrol negative.

8. Analisis Data mengenai efek immunodulator diolah secara statistic menggunakan kruskalwallis test dengan SPSS untuk pengujian statistiknya, sedangkan untuk penentuan kriteria dari immunodulator dilakukan dengan menghitung regresi linear dari \% nilai serapan dari waktu ke-4 sampai waktu ke-16 dan selanjutnya hasil regresi linear perlakuan dibandingkan dengan hasil regresi kontrol negatif.

\section{Hasil dan Pembahasan}

Determinasi Tanaman, hasil determinasi menyatakan bahwa tanaman yang diteliti adalah Allium cepa L, Familia Ammaryllidaceae/ Alliaceae/ Liliaceae dengan referensi Sp.PI. 1:300. 1753 [1 may 1753] (IK), Yang berarti tanaman sesuai dengan yang akan digunakan.

Proses ekstraksi, diperoleh Ekstrak kental umbi bawang merah (Allium cepa L) sebanyak 26,8 gram dan hasil rendemen yang dihasilkan adalah $10,72 \%$, yang menunjukkan ekstrak baik $(>10 \%)$

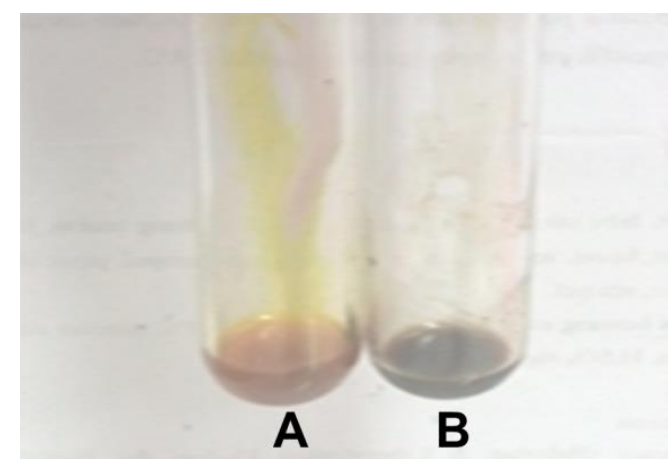

Gambar 1. Hasil Uji Flavonoid (A) ekstrak ditambah $\mathrm{NaOH}$, positif mengandung flavonoid (B) ekstrak ditambah I tetes $\mathrm{FeCl}_{3}$, positif mengandung flavonoid (Jatmiko, 2015). Dapat dikatakan bahwa ekstrak yang dibuat positif mengandung flavonoid.

Uji Aktivitas Immunodulator, yang meliputi Operating time $\mathbf{3 0}$ menit (didapatkannya darah dan larutan serum disentrifuge (10 menit), didiamkan (20 menit)). Penetapan kadar karbon diperoleh kadar karbon sebanyak 41,4\%. Kurva Baku Karbon yaitu dilihat dari nilai $r \quad$ 0,966 yang menyatakan bahwa ada hubungan antara konsentrasi dan absorban. Hasil untuk Uji Carbon Clearance ada pada tabel 1.

Tabel 1. Kecepatan Fagositosis dalam Eliminasi Partikel Karbon Darah Mencit Jantan Galur Balb/C

\begin{tabular}{cccccc}
\hline Kelompok Perlakuan & \multicolumn{5}{c}{ Nilai \% serapan $(100$ - \%transmitan ) pada menit ke- } \\
\hline I & 0 & 4 & 8 & 12 & 16 \\
II & 48,010 & 64,055 & 59,682 & 59,240 & 54,215 \\
III & 42,724 & 58,550 & 55,314 & 51,605 & 47,324 \\
IV & 44,165 & 58,742 & 59,030 & 54,670 & 49,282 \\
V & 44,063 & 59,049 & 57,090 & 53,262 & 49,636 \\
& 45,814 & 64,829 & 58,088 & 53,411 & 50,181 \\
\hline
\end{tabular}

Keterangan : I : Kontrol negatif, II : kontrol positif (imboos), III : dosis $12 \%$ (v/v), IV : dosis $24 \%(\mathrm{~V} / \mathrm{v}), \mathrm{V}:$ dosis $48 \%$ (v/v)

Tabel 2. Hasil Analisis Aktivitas fagositik bahan uji dengan metode Carbon Clearance pada Mencit Jantan Galur Balb/C.

\begin{tabular}{cccc}
\hline Kelompok Perlakuan & Koefisien Regresi & Indeks Fagositosis (ku/kk) & Efek Immunostimulator \\
\hline I & $-0,661$ & 1 & kontrol \\
II & $-0,977$ & 1,478 & Immunostimulan \\
III & $-0,900$ & 1,361 & Immunostimulan \\
IV & $-0,949$ & 1,435 & Immunostimulan \\
V & $-0,958$ & 1,449 & Immunostimulan \\
\hline
\end{tabular}

Keterangan : I : Kontro negatif, II : kontrol positif (imboos), III : dosis 12\% (v/v), IV : dosis $24 \%$ (v/v), V : dosis $48 \%$ $(\mathrm{v} / \mathrm{v}), \mathrm{ku}:$ koefisien regresi kelompok perlakuan, kk : koefisien regresi kelompok kontrol. 
Berdasarkan tabel 1 dapat diketahui bahwa terjadi penurunan nilai absorban pada semua kelompok perlakuan dibandingkan dengan kelompok kontrol. Hal tersebut memperlihatkan bahwa terjadi peningkatan aktivitas fagositosis. Hal tersebut diperkuat oleh pendapat Baratawidjaja (2010) yang menyatakan jika IFN-Y yang diproduksi berbagai sel sistem imun merupakan sitokin utama MAC (Macrophage Activating Cytokine) dan berperan terutama dalam imunitas non spesifik seluler. IFN-y adalah sitokin yang dapat mengaktifkan makrofag, sehingga makrofag mengalami peningkatan aktivitas fagositosis secara cepat dan efisien dalam menyingkirkan antigen.

Pada tabel 2 dapat diketahui pemberian dosis $12 \%(\mathrm{v} / \mathrm{v})$ diperoleh nilai rata-rata indeks fagositosis sebesar 1,478 (IF > 1) yang berarti pemberian dosis ekstrak etanol umbi bawang merah mempunyai efek immunodulator. Kelompok perlakuan kontrol positif, pemberian dosis $24 \%$ (v/v) dan $48 \%$ (v/v) mempunyai nilai rata-rata indeks fagositosis lebih dari satu (IF >1), hal ini menunjukkan berarti kelompok perlakuan kontrol positif, pemberian dosis $12 \%(\mathrm{v} / \mathrm{v}) ; 24 \%(\mathrm{v} / \mathrm{v})$ dan $48 \%$ (v/v) mempunyai kemampuan meningkatkan sistem pertahanan tubuh terhadap aktivitas fagositosis sel fagositik. Kelompok perlakuan dengan pemberian dosis $12 \%$ (v/v); $24 \%$ (v/v) dan $48 \%(\mathrm{v} / \mathrm{v})$ mempunyai aktivitas fagositosis yang

\section{Daftar Referensi}

Aldi, yufri. 2013. Uji Imunomodulator Beberapa Subfraksi Ekstrak Etil Asetat Meniran (Phyllanthus Niruri [L]) Pada Mencit Putih Jantan Dengan Metoda Carbon Clearance. Prosiding Seminar Nasional Perkembangan Terkini Sains Farmasi Dan Klinik III 2013 UJI, 2339-2592, 13447.

Anonim ${ }^{1}$. 2016. Bawang Merah. Diakses dari: www.ms.wikipedia.org. diakses tanggal 17 Oktober 2016.

Anonim $^{2}$. 2007. Cucumber Salad With Watermelon: What's Coookin'. diakses dari:

http://healthcorner.walgreens.com/display/ 1361.htm . diakses tanggal 17 Oktober 2016.

Anonim $^{3}$. 2014. Bawang Merah. Nanotech herbal Indonesia. Diakses tanggal 17 oktober 2016.

Badan Penelitian dan Pengembangan Pertanian. 2007. Prospek dan Arah Pengembangan Agribisnis: Bawang Merah. diakses dari: www.litbang.deptan.go.id tanggal 17 Oktober 2016. lebih rendah dibandingkan dengan aktivitas fagositosis dari kelompok kontrol positif.

Hasil pengujian statistik yang dilakukan Berdasarkan pengukuran tersebut didapatkan hasil bahwa dari masing-masing kelompok perlakuan terhadap kontrol terdapat perbedaan nyata $(P<0,05)$., Terdapat perbedaan yang signifikan yang dilihat dari uji Post Hoc Test yang memperlihatkan bahwa ada perbedaan yang nyata antar kelompok perlakuan $(\mathrm{P}<0.05)$.

\section{Simpulan}

Ekstrak etanol umbi bawang merah mempunyai efek aktivitas immunomodulatory terhadap respon imun non spesifik pada mencit jantan galur balb/c dengan metode carbon clearance

Kelompok perlakuan kontrol positif, pemberian ekstrak etanol umbi bawang merah dengan dosis 12\%(v/v); $24 \%(\mathrm{v} / \mathrm{v})$ dan $48 \%(\mathrm{v} / \mathrm{v})$ mempunyai kemampuan meningkatkan sistem pertahanan tubuh terhadap aktivitas fagositosis sel fagositik.

Pemberian ekstrak etanol umbi bawang merah dengan dosis $12 \%(\mathrm{v} / \mathrm{v})$, dosis $24 \%(\mathrm{v} / \mathrm{v})$ dan, dosis $48 \%(\mathrm{v} / \mathrm{v})$ mempunyai kemampuan immunostimulan yang lebih rendah dari kontrol positif.

Bellanti, J.A., 1993. Immunologi III, George University School Of Medicine, Washington DC.

Baratawidjaja KG. 2009. Imunologi Dasar. Edisi ke-10. Balai Penerbit FKUI. Jakarta.

Baratawidjaja KG. 2006. Imunologi Dasar. Edisi 7. Balai Penerbit FKUI. Jakarta. 412-428.

Block, K. I., Mead, M. N. 2003. Immune System Effects of Echinacea, Ginseng and Astragalus: A review. Integrative Cancer Therapies 2 (3), $247-267$.

Cuppett, S., M. Schrepf and C. Hall III. 1954. Natural Antioxidant - Are They Reality. Dalam Foreidoon Shahidi: Natural Antioxidants, Chemistry, Health Effect and Applications, AOCS Press, Champaign, Illinois: $12-24$.

Chairul, dan Praptiwi. 2000. Uji Efektivitas Imunomodulator Tiga Jenis Zingiberaceae Secara In-Vitro Melalui Pengukuran Aktivitas Sel Makrofag dan Kapasitas Fagositosis, Botani. Puslit. Biologi., LIPI, Cibinong.

Corwin, E. J. 2009. Buku saku patofisiologi (Egi Komara, Esty Wahyuningsuh, Devi 
Yulianti, dan Pamilih Eko Karyuni, Penerjemah) . Jakarta: EGC. Departemen

Ditjen POM, 1986. Sediaan Galenik . Departemen Kesehatan RI : Jakarta.

Ebook pangan. 2006. Khasiat dan Pengolahan (teori dan praktek).

Federer, W. T. 1967. Experimental Design: Theory and Application. Oxford \& IBH Publishing Co. New Delhi. 544 pp.

Hartono. 2008. Fraksi Etil Asetat Ekstrak Etanol Seledri ( Apium Graveolens L.) Pada Kelinci Putih Jantan Galur New Zealand Nugroho Sri Hartono K 100040062.

Hendarsula. 2011. Uji Aktivitas Imunostimulan Ekstrak Etanol Umbi Sarang Semut (Myrmecodia Archboldiana Merr. \& L.M. Perry) Pada Tikus Putih Jantan, Annisa Rahma Hendarsula, FMIPA UI, 2011. Skripsi.

Irawan, D. 2010. Bawang Merah dan Pestisida. Badan Ketahanan Pangan Sumatera Utara. Medan. http://www.bahanpang.sumutprov.go.id Diunduh 12 November 2016.

Jaelani, 2007, Khasiat Bawang Merah, Kanisius, Yogyakarta. 3.

Jatmiko, S. 2015. Efek Imunomodulator Fraksi Etil Asetat Daun Tempuyung (Sonchus Arvensis L.) Terhadap Respon Imun Non Spesifik Pada Mencit Jantan Galur Balb/C. Pharmaçiana, 31, 1-7.

Kumala, S. 2007. Efek Imunomodulator Ekstrak Daun Ketepeng Cina ( Cassia Alata L .) Terhadap Aktivitas Dan. Makara, Kesehatan, Vol. 11, No. 2, Desember 2007: 50-53 Efek, 11(2), 50-53.

kusmardi. 2007. Efek Imunomodulator Ekstrak Daun Ketepeng Cina ( Cassia Alata L .) Terhadap Aktivitas Dan Kapasitas Fagositosis Makrofag. Makara, Kesehatan, 11(2), 50-53.

Nawangsari. 2008. Pemanfaatan Bawang Merah ( Allium cepa L .) sebagai Agen KoKemoterapi. Karya Tulis Mahasiswa, (FAKULTAS FARMASI UNIVERSITAS GADJAH MADA YOGYAKARTA), 1-36.

Rahayu, E, dan Berlian, N. V.A . 1999. Bawang
Merah. Penebar Swadaya. Jakarta. Hal 4.

Redha, A. 2010. Flavonoid: Struktur, Sifat Antioksidatif dan Peranannya Dalam Sistem Biologis. Jurnal Berlin, 9(2), 196202.

Robinovitch, M. Proffesional and non-Proffesional Phagocytes an Introduction. Trends In Cell Biology; 1995. Vol : 5, Hal. 85-87.

Robinson, T. 1995. Kandungan Organik Tumbuhan Tinggi. Edisi ke-4 Terjemahan Kosasih Padmawinata. ITB Press. Bandung.

Rodrigues A., Fogliano V., Graziani G., Mendes, S., Vale, A. And Goncalves, C. 2003. Nutrition Value of Onion Regional Varieties in Northwest Portugal. EJEAFChe 2(4):519-524.

Shrestha, H. 2007). A plant monograph on onion. The School of Pharmaceutical Ans Biomedical Sceinces, Magister S(11), 90.

Singh. (2012). Immunomodulatory activity of butanol fraction of Gentiana olivieri Griseb. on Balb/C mice. Asian Pacific Journal of Tropical Biomedicine, 2(6), 433-7. https://doi.org/10.1016/S22211691(12)60071-9

Soepomo, J. P. 2015. Meningkatkan Aktivitas Fagositosis Makrofag Tikus Betina Galur Sd ( Sprague Dawley) Yang Diinduksi Dmba ( 7 , 12dimetilbenz ( A ) Antrasen ) Secara In Vitro The Effects Of Hexane Extracts From Black Cumin Seeds To The Phagocytic Activity Of Macrophages S. Pharmaçiana, 5, 69-76.

TIZARD, I.R. 2000. Immunology: An Introduction. 6th Ed. New York: Saunders College Publishing. pp. $98-161$.

Usmar. 2013. Potensi Efek Imunomodulator Dari Ekstrak Umbi Bawang Dayak (Eleutherine Americana (Aubl) Merr.) Pada Mencit (Mus Musculus). Pharmaçiana, 53, 1-8.

Wibowo, S. 2001. Budidaya Bawang: Bawang Putih, Merah, dan Bombay. Penebar Swadaya: Jakarta.

Wiedosari, E. 2007. Peranan Imunomodulator Alami (Aloe Vera) Dalam Sistem. Wartazoa, 17(4), 165-171. 